\title{
The coherent variability of African river flows: Composite climate structure and the Atlantic circulation
}

\author{
Mark R Jury \\ Environmental Studies Dept., University of Zululand, South Africa
}

\begin{abstract}
The composite structure of the ocean and atmosphere around Africa is studied in the context of river flow variability. Annual streamflows are analysed for the Blue and White Nile, Congo, Niger, Senegal, Zambezi, and Orange Rivers, and inflow to Lake Malawi. Spectral energy is concentrated in 6.6- and 2.4-year bands. The interannual variability of many river flows is significantly cross-correlated $(\mathrm{p}<.05)$ over the period 1950-1995, following removal of the mean trend. A combined river flow index indicates that flows were highest in 1961, 1962, 1968, 1977, 1978 and lowest in 1971, 1972, 1982, 1983, 1991.

Forming a composite of differences between high- and low-flow years, SST anomalies and other atmospheric fields are investigated to better understand climatic factors driving hydrological extremes. During high flows, NCEP reanalysis data reveal a composite La Nina event off Peru-Ecuador. SST patterns reveal an inter-hemispheric dipole in the Atlantic (eg. warm - north) and below normal SST in the west Indian Ocean during years with high flow. The equatorial east Atlantic undergoes warming through the 'composite year' in a manner consistent with its opposing response to the Indo-Pacific La Nina. Tropical upper winds are easterly and symmetrical about the equator, and may explain why inter-annual variability of river flows south of the equator are correlated with those of the north at 6-month lag. Low level westerly winds are greater during high flow years, particularly along the Guinea coast. Differences of OLR and upper velocity potential demonstrate two distinct centers of action either side of the tropical Atlantic. It is concluded that hydrological events over Africa and South America are sensitive to tropical Atlantic coupling with the global El Nino - Southern Oscillation signal.
\end{abstract}

\section{Introduction}

Ancient civilizations in Africa were dependent on a regular flow of water in the Nile, and in other major rivers: Niger, Congo, Senegal, Zambezi, and Orange; and the rift valley lakes: Victoria and Malawi. These water resources nurtured the evolution of man and enabled societal and economic advances. Their statistics are impressive: the Nile extends $6650 \mathrm{~km}$ in length, the Congo yields an annual runoff of $1250 \mathrm{~km}^{3}$, whilst the volume of Lake Malawi is $7200 \mathrm{~km}^{3}$. However, Africa's rivers flow irregularly and fluctuations over millennia have occurred as a result of changes in the overlying monsoons.

Intra-decadal climate variability is pronounced along the margins between the tropics and the semi-arid African savanna (Nicholson,1981). Despite the risk of multi-year drought and flood, over 100 million people engage in agricultural activities there. Whilst the seasonal cycle of rainfall can be anticipated, runoff is such a small fraction of rainfall that vulnerability to climate impacts is high in Africa. Farquharson and Sutcliffe (1998) show that runoff is less than $10 \%$ of rainfall in areas where the seasonal total is less than one metre. In contemporary times, an explanation for the interannual fluctuation of African river flows has remained elusive (Servat et al., 1998). The flow of the Nile and Congo Rivers is influenced by the Pacific El Nino - Southern Oscillation (ENSO) phase (Amerasekara et al., 1997); so it is thought that further research on year-to-year changes in tropical climate may lead to a better understanding of hydrological extremes in Africa. Interaction between the regional circulation of the tropical Atlantic and convective patterns over the adjacent continents is the subject of this paper.

\footnotetext{
* To whom all correspondence should be addressed.

蒕035-9026326; fax 035-9026317; e-mail: mjury@pan.uzulu.ac.za Received 4 January 2002; accepted in revised form 23 October 2002.
}

\section{The tropical Atlantic}

The tropical Atlantic Ocean and its overlying atmosphere contain many similarities with the equatorial Pacific in terms of air-sea coupling processes. Although warm events similar to El Nino occur in the Atlantic, it is a narrower ocean basin and the continental influences of South America and Africa are more apparent. The asymmetry of the African landmass with respect to the adjacent ocean basin induces a north-south temperature gradient and a monsoon regime over the Gulf of Guinea. To the west, deep convection is confined to a narrow strip that spans the Atlantic Ocean with a northward tilt toward Africa (Servain et al., 1998). The inter-tropical convergence zone (ITCZ) over the east Atlantic experiences a seasonal migration, from $14^{\circ} \mathrm{N}$ in August to the equator in March. This region of moisture flux convergence and latent heating overlies higher sea surface temperature (SST). South of the equator south-easterly trades are strong and steady. Equatorial and coastal upwelling induces cooler SSTs and stratiform clouds there. In the Gulf of Guinea winds are more meridional and rotate clockwise becoming more westerly over Africa, in the process modulating inflow to continental rainfall regimes. Most of the tropical Atlantic gains heat radiatively and evaporation losses are found to be low (Hastenrath and Lamb, 1978). Cyclonic wind stress west of Angola produces an uplifted thermocline, which is sensitive to ocean-atmosphere coupling processes (Jury et al., 2000).

Studies of inter-annual climate variability have revealed two Atlantic modes: an equatorial ENSO-type every 2 to 5 years; and opposing sea surface temperature (SST) anomalies in northern and southern subtropics with a more decadal rhythm (Servain et al., 1998). Basin-scale winds and associated equatorial waves play a significant role in the generation of SST anomalies and coherent atmospheric responses and impacts (Nicholson and Entekhabi, 1987; Servain, 1991; Zebiak, 1993; D’Abreton and Lindesay, 1993; Curtis and Hastenrath, 1995; Mehta and Delworth, 1995; 


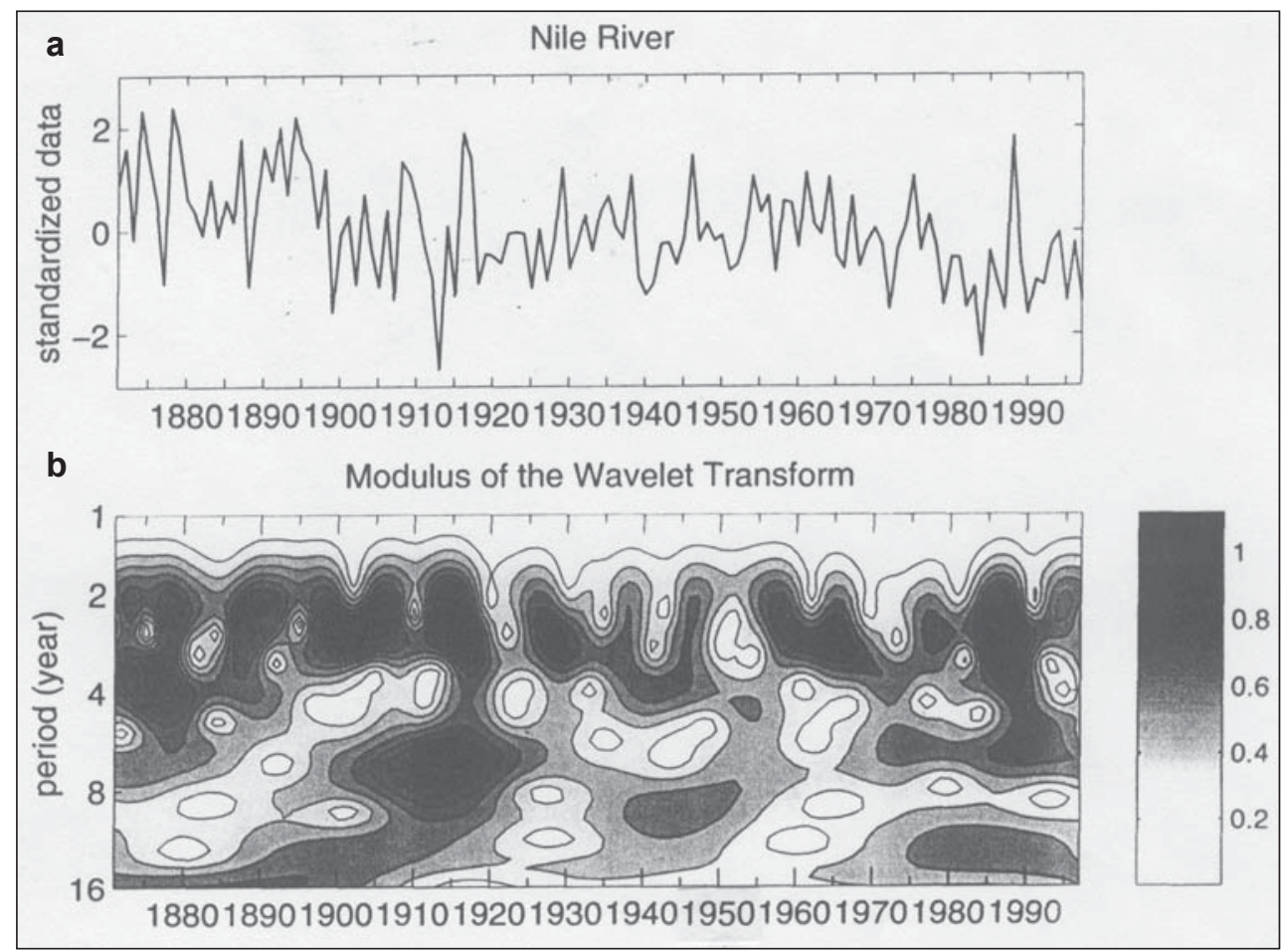

Figure 1

Time series of annual flow departures (in sigma) for the Blue Nile (a) and its periodic structure analysed by wavelet transform (b).

Spectral energy is found in the 2 to 4 year range.
Huang et al., 1995; Tourre et al., 1999). Interannual variability is found to be weak and unstable compared with the tropical Pacific. ENSO signals in the Atlantic may be identified through shifts of the ITCZ and associated wind shear. Tourre and White, (1995) and Delecluse et al., (1994) indicate that ENSO coupling in the tropical Atlantic is part of a global perturbation, which can explain a significant portion of African rainfall variability (Hastenrath, 1990; Ropelewski and Halpert, 1987). It is the intention of this paper to add to this research on linkages between African climate, the tropical Atlantic and ENSO.

In the North Atlantic, the atmospheric circulation is dominated by low frequency adjustments of pressure known as the North Atlantic Oscillation (Lamb and Peppler, 1987; Deser and Blackmon, 1993; Kushnir, 1994; Hurrell, 1995). Alternating bands of high and low pressure and related wind stress anomalies extend from the mid-latitudes through the tropics and modulate the latitudinal disposition of rainfall over Africa (Houghton and Tourre, 1992; Enfield and Mayer, 1997; Servain et al., 1998; Lamb, 1978; Hirst and Hastenrath, 1983; Folland et al., 1986; Lough, 1986; Lamb and Peppler, 1987; Wagner and daSilva, 1994; Janicot et al., 1996; Jury, 1997, Ward, 1998). A question to be considered in this study is - How do circulation patterns over the tropical Atlantic produce widespread convective anomalies over Africa?

\section{African climate and river flows}

Observational studies using composites of extreme rainfall seasons in West Africa have revealed a consistent N-S dipole structure in SST (Hastenrath and Heller, 1977; Moura and Shukla, 1981; Wolter, 1989). Servain's (1991) dipole index showed significant correlation with regional precipitation in South America and Africa. In addition to the meridional displacement of the ITCZ, the stability of low level air affects precipitation well north of the Guinea coast (Fontaine et al., 1995, Eltahir and Gong ,1996) where west African rivers (the Senegal and Niger) are fed.

The Nile River flow has been extensively studied. Its normalised streamflow gauge time series is shown in Fig. 1a; whilst cyclical behaviour is analysed in Fig. 1b. Spectral energy is greatest in the 2 to 4 year range, although some decadal energy is apparent. Fluctuations have been linked to the global ENSO (Quinn 1992, Eltahir 1996), as defined by Pacific SST and the southern oscillation index (SOI) of zonal pressure. The correlation between the Nile flow and the Pacific Nino3 SST index in the period 1871 to 1997 is -0.54 at zero lag (Eltahir and Wang, 1999). Warming in the equatorial eastern Pacific causes an indirect circulation and sinking motion over the source of the Nile. Less rain falls over Ethiopia in the June-October season leading into an El Nino event. This Nile - ENSO association, first outlined by Bliss (1925) in the context of the southern oscillation, is unstable at times yet offers predictive potential. If many of the other rivers in Africa are correlated with the Nile and with each other, then understanding ENSO responses across the oceans near Africa would enable the application of widespread mitigation strategies. The known response of the tropical Atlantic to ENSO (Saravanan and Chang, 2000) is likely to create opposing climatic conditions over parts of South America, so this hypothesis is tested with the results presented here.

\section{Data and methods}

To understand the inter-annual variability of river flows across Africa; annual streamflow data were obtained for a number of rivers (see Fig. 2 a), including:

- Blue Nile, tributary at Roseris, Sudan, draining the Ethiopian highlands,

- White Nile, outflows at Jinja, Uganda from Lake Victoria,

- Niger at Koulikoro, Mali, draining Guinea,

- Senegal at Bakel, draining eastern Senegal / western Mali

- Congo at Brazzaville, draining the northern and central basin,

- Zambezi at Victoria Falls, draining western Zambia,

- Orange above Gariep dam, draining the Lesotho highlands

- Malawi Lake inflows. 
The data are based on quality-checked hydrographic records, naturalized for known anthropogenic effects (eg. dams built), and published in scientific reports. The time series were available from 1950 to 1995 as cumulative streamflow in $\mathrm{km}^{3}$ per year. In the case of Lake Malawi, changes in its level from the lowest to the highest point of the rainy season were obtained. Eltahir (1996) and Farquharson and Sutcliffe (1998) have analysed the seasonal cycle using monthly records. Southern African streamflow increases from January to April. Northern rivers exhibit highest flows from July to October. Annual streamflow data are assumed to represent the cumulative seasonal behaviour, and generally exhibit close agreement with catchment rainfall, with a 1 to 2 month lag in most cases. The hydrographic data, except for the flows from Lakes Victoria and Malawi, contained near-linear trends averaging -1\% per annum in the 1950-1995 period. These could be attributed to multi-decadal oscillations in rainfall and to the secondary effects of agricultural use and human consumption. To investigate year-to-year variability a more stationary record is necessary, so the average downtrend was removed. The annual records were analysed for auto-correlation and Pearson's product crosscorrelations were calculated over the 45 year period. Finally, an index of African water resource variability was constructed from the five time series exhibiting significant cross-correlations. The distribution of African streamflow gauges used in this study is shown in Fig. 3a. To support the hypothesis of opposing hydrological behaviour in South America, streamflow data for the Amazon and Parana Rivers are compared using similar statistical methods.

To establish climatic factors governing fluctuations in continental-averaged streamflow, National Centre for Environmental Prediction (NCEP) reanalysis data were consulted. This data set provides monthly averages of numerous atmospheric fields from 1958 to present. The observations are model-reconstructed as described by Kalnay et al. (1996). Here use is made of winds at three levels: surface, $3 \mathrm{~km}$ and $12 \mathrm{~km}$, estimates of convective activity from outgoing longwave radiation, and two indicators of circulation - the streamfunction (rotational flow) and velocity potential (divergent flow). Observational densities vary through the record and may influence the result. Surface data inputs increased over most of Africa after 1958; however, over West Africa data densities increased significantly after 1967 . Hence evidence for some of the earlier wet years may be less reliable. Oceanic influences are characterised by SST. Ship data densities were highest over the tropical Atlantic in the period 1968 to 1988. Although radiosonde profile inputs have been consistent throughout the period, aircraft and satellite wind data increased after 1978 and 1988 respectively.

To describe climate teleconnections affecting African river flows, a hemispheric scale domain of analysis is utilized and gridded data are averaged over annual or half-yearly periods, following tests to determine stability of the pattern. Environmental conditions for the five years with highest river flows: 1961, 1962, 1968, 1977, 1978 are contrasted with five years with lowest flows:
1971, 1972, 1982, 1983, 1991 by subtraction of the low-flow composite field from the high-flow field. The aim is to place hydrological events over Africa into a regional context, and to consider which climatic signals are present. The intra-composite consistency is evaluated for key areas and biases are identified. The low-flow years occur, on average, about a decade later than highflow years, during which time the low-frequency Atlantic SST dipole acted to inhibit West African rainfall (diverting the ITCZ). Hence the interaction of mixed ENSO and Atlantic dipole modes may be assessed in the composite. It is pointed out that the western Pacific is omitted in the illustrations, as environmental differences there are small and apparently inconsequential.

\section{Results}

\section{Temporal analysis of river flows}

Table 1 provides details of trend, persistence and association. Many rivers still have downward trends after removal of the mean. 


\begin{tabular}{|c|c|c|c|c|c|c|c|c|c|}
\hline \multicolumn{10}{|c|}{$\begin{array}{c}\text { TABLE } 1 \\
\text { Statisitics for annual river series 1950-1995 }\end{array}$} \\
\hline \multirow[b]{2}{*}{ River } & \multicolumn{9}{|c|}{ Cross-correlation (\%) } \\
\hline & RT & $A C+1$ & wNile & Niger & Cong & Zamb & Oran & Malw & Seng \\
\hline - Blue Nile & 0 & 9 & -4 & 36 & 28 & 33 & 27 & 34 & 47 \\
\hline - White Nile* & 0 & 78 & & 1 & 60 & 35 & -6 & 26 & 0 \\
\hline - Niger & -2.0 & 49 & & & 32 & 36 & -11 & 7 & 57 \\
\hline - Congo & -0.5 & 61 & & & & 56 & 5 & 40 & 22 \\
\hline - Zambezi & -1.1 & 42 & & & & & 19 & 54 & 25 \\
\hline - Orange & 0 & 19 & & & & & & 0 & 23 \\
\hline - Malawi* & 0 & 1 & & & & & & & -4 \\
\hline - Senegal & -1.5 & 53 & & & und & erlined & (B) withir & index & \\
\hline \multicolumn{10}{|c|}{$\begin{array}{l}\mathrm{N}=45 \text { sample size } \mathrm{DF} \sim 22 \text { degrees of freedom } \\
\text { Significant correlations in bold }(\mathrm{p}<.05), *=\text { no trend in original data, } \\
\mathrm{RT}=\text { residual trend in } \% \text { per annum, } \mathrm{AC}+1=\text { auto-correlation in year }+1\end{array}$} \\
\hline
\end{tabular}

edges of the Africa's rainy belt. Much of East Africa, which experiences a dry boreal summer, is known to receive surplus rainfall during the ENSO warm phase (Ogallo et al., 1988; Kabanda, 1995), hence the generally weaker relationships for the White Nile (Lake Victoria). Cross-correlations between the Zambezi, Congo, Blue Nile, Niger and Malawi flows are sufficient $(p<.05)$ to justify combining their individual standardized departures into a single African river index (Fig. 2b), which is geographically balanced: with two south, one central and two northern rivers. The highest year on record is 1961 (Lake Victoria rose $\sim 2 \mathrm{~m}$, yet ENSO amplitude was minimal). Other high-flow years are of comparable magnitude. Low-flow years include the 1983 El Nino event, and the years leading into the El Ninos of 1973 and 1992. The cross-correlations

The Niger is amongst the most desiccated since 1950, followed by the Senegal. Sahel rainfall corroborates the drying trend across West Africa over the four decades considered here. The Zambezi exhibits a drying trend; however, catchment rainfall is quite stationary. The auto-correlation at one-year lag, as a measure of persistence, suggests that equatorial water resources are least variable. The White Nile (78\%) is followed by the Congo (61\%) and experience bimodal rainy seasons. The Niger, Senegal and Zambezi Rivers are swept by unimodal rainy seasons controlled by the latitude of inter-tropical convergence. Auto-correlation is in the range $42 \%$ to $53 \%$, the catchments lie west of $20^{\circ} \mathrm{E}$, and rainfall is more influenced by the tropical Atlantic. Further east, the Orange and Blue Nile Rivers and Lake Malawi exhibit higher frequency variability, presumably of ENSO and biennial type contributed from the Indian Ocean. The residual persistence $(\mathrm{AC}+1)$ in the hydrological time series requires that the degrees of freedom be deflated by a factor of two.

Spectral characteristics of annual river flows over the period 1950 to 1995 are as follows:

- Blue Nile, 2.7 year cycle dominant, secondary cycles at 6.6 and 15.3 years,

- Congo, 6.6 and 15.3 year cycles present, quasi-biennial cycle absent

- Orange (in the south), 15.3 cycle present, quasi-biennial cycle at 2.3 years

- Zambezi, most spectral energy around 5.6 years

- White Nile (Lake Victoria outflow), 'step' increase in 1962 disturbs cyclic analysis

- Niger and Senegal, multi-decadal trends are dominant.

- Malawi inflow, spectral energy at 7.7 and 5.6 years, quasibiennial at 2.4 years.

When all rivers are combined, spectral energy is strongest at 6.6 years, whilst a secondary cycle is present at 2.4 years. Multidecadal trends give rise to an artificial cycle near the record length (46 years). The 6.6 year cycle is consistent with low-frequency ENSO variability, whilst the 2.4 year cycle may be modulated by the quasi-biennial oscillation of stratospheric momentum.

Cross-correlations are high for a number of rivers, but lower for the Orange, Senegal and White Nile. The first two are at the poleward listed in Table 1 are calculated within the calendar year, eg. southern flows from January to April are compared with northern flows from July to October. Calculated the other way, with the northern rivers leading by 6 months, cross-correlations are of similar magnitude. Hence the climatic forcing contains such memory that both austral and boreal summers are similarly affected, and meridional or seasonal propagation is not a strong concern.

\section{Composite climatic structure}

The NCEP reanalysis data for composite high- and low-flow years identify the large-scale ocean and atmospheric conditions necessary for the development of extreme hydrological events across Africa. As mentioned earlier, sensitivity tests with different combinations of rivers listed in Table 1 and years (6-month lead or lag), gave essentially similar results. SST difference fields for the $1^{\text {st }}$ and $2^{\text {nd }}$ half of the composite year are shown in Figs. $3 a$ and $3 b$ together with river gauge positions. In the January to June period when southern rivers are flowing most strongly, SST differences (in high-flow years) indicate below-normal temperatures off the coasts of Peru and Ecuador. This oceanic pattern is consistent with La Nina conditions in the eastern equatorial Pacific. SST differences are also negative in the subtropical South Atlantic and in the tropical western Indian Ocean. The subtropical north Atlantic is warmer than usual and creates the dipole pattern known to anticipate good rains across the Sahel.

In the July to December period La Nina conditions persist and strengthen in the eastern Pacific and west Indian Ocean. At this time of the year, the northern water resources are replenished. Although many of the oceanic features are persistent, considerable warming occurs in the tropical South Atlantic. An equatorial plume of positive SST differences spreads west from Gabon and Angola with respect to high-flow years. Warming is also found around the perimeter of the South Atlantic high-pressure cell along $35^{\circ} \mathrm{S}$. These changes in the marine environment are coupled to an atmospheric circulation response.

Surface wind differences are illustrated in Fig. 4a for the composite calendar year. Across most of the North Atlantic, westerly winds are evident and exhibit axes of significant differences near $35^{\circ} \mathrm{N}$ and over the equatorial Atlantic. The flow rotates cyclonically over West Africa during high-flow years, bringing 


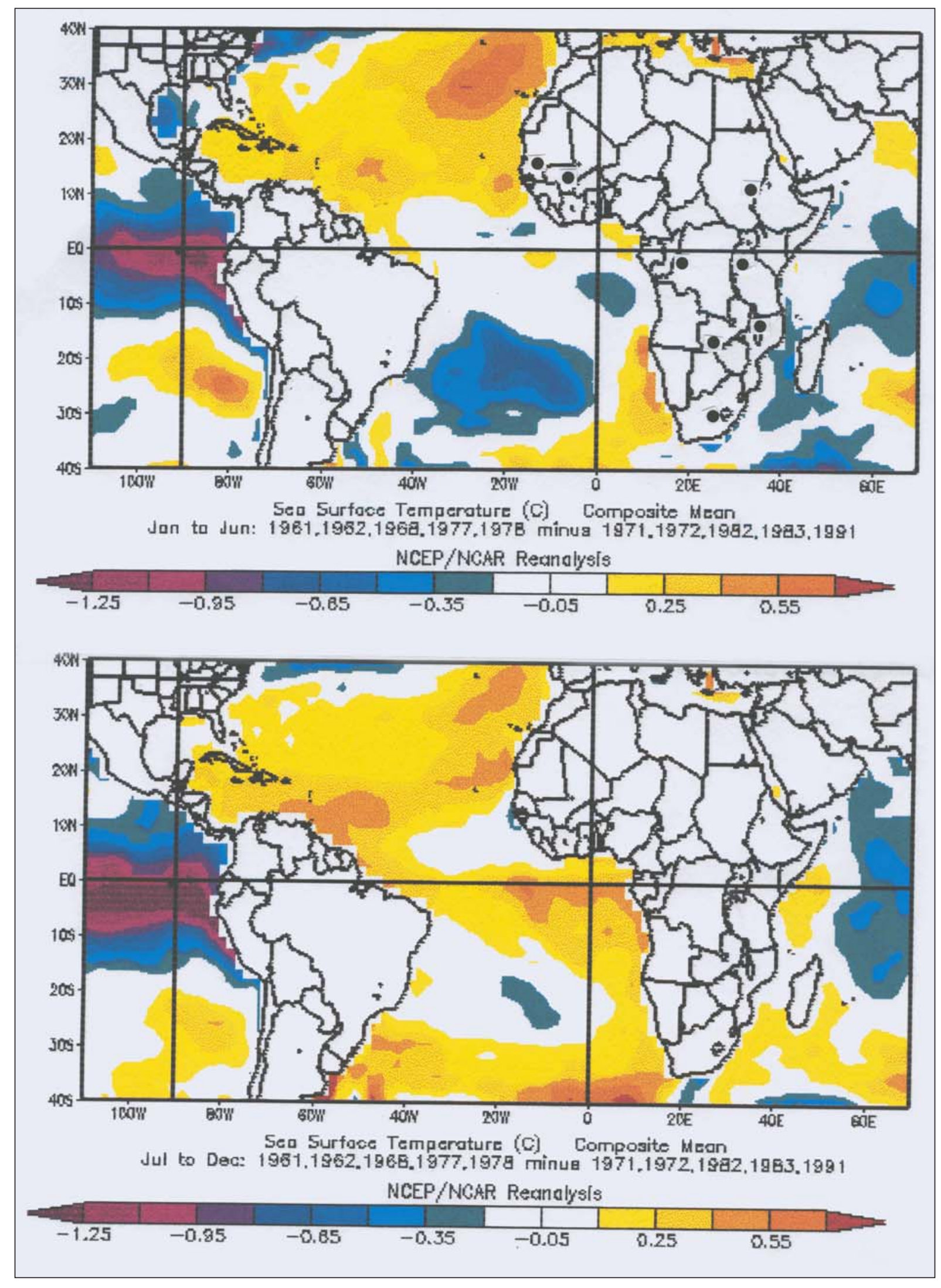

Figure 3

SST differences for the $1^{\text {st }}$ (a) and $2^{\text {nd }}$ (b) half of the composite year. Colour bar lower. Patterns are an average of highflow years minus low-flow years. Dots in upper panel refer to river gauge positions. 


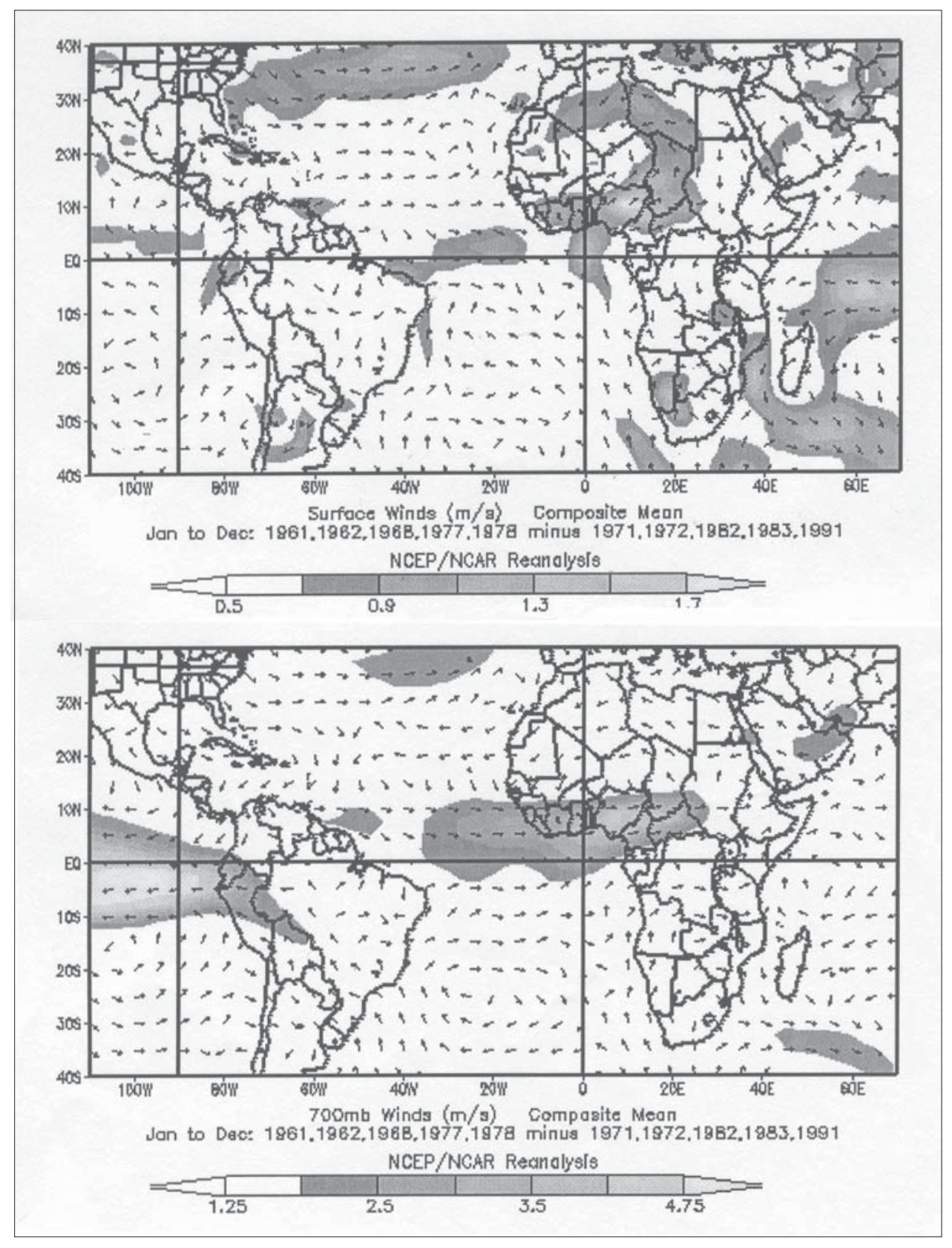

Figure 4

Surface (a) and $700 \mathrm{hPa}$ level (b) vector wind differences for the composite year. Shading refers to areas where circulation differences are significant. a singular axis of westerly wind differences is found along the Guinea coast. The anomalous flow interacts with the African easterly jet associated with convective wave trains across the Sahel (Thorncroft, 1995), providing additional cyclonic vorticity in rainy years. The two axes of flow differences align on $5^{\circ} \mathrm{S}$ in the Pacific and on $5^{\circ} \mathrm{N}$ in the Atlantic, as the continental asymmetry dictates. Lowlevel divergence is inferred across South America. Over the subtropical South Atlantic, cyclonic circulations represent a weakening of the highpressure cell associated with the SST warming trend. Descending (ascending) motions occur at the western (eastern) end of the tropical Atlantic wind axis, in this composite scenario.

Upper level wind differences (Fig. 5a) are dominated by enhanced easterly flow over the tropical Atlantic $\left(10^{\circ} \mathrm{S}\right.$ to $20^{\circ} \mathrm{N}, 0$ to $60^{\circ} \mathrm{W}$ ) which bifurcate over Africa into two sub-tropical axes. The northern axis lies along $20^{\circ} \mathrm{N}$ and supports the tropical easterly jet emanating from India in the boreal summer, whilst the southern axis lies along $15^{\circ} \mathrm{S}$. In the mid-latitudes of the north Atlantic and over South Africa, upper wind differences are westerly. The circulation creates a ' $<$ '-shaped streamfunction (rotational circulation) pattern (Fig. 5b) extending from the western tropical Atlantic symmetrically across Northern and Southern Africa.
Guinea monsoon air northward into the Sahelian zone. There is a circulation response in the Indian Ocean, fueling convective activity over the Southern African catchments. Easterly wind differences from the equatorial South Indian Ocean are drawn toward Africa along $10^{\circ} \mathrm{S}$ and converge with poleward flowing monsoon air across the eastern highlands and Zambezi Valley. The Indian easterlies (Atlantic westerlies) overlie lower (higher) SST, suggesting that evaporative fluxes and equatorial upwelling dynamics sustain the oceanic features.

Wind differences at the $700 \mathrm{hPa}$ level (Fig. 4b) exhibit a more coherent pattern coupled with ENSO. Over the eastern Pacific, enhanced easterlies are present in the composite circulation pattern. These provide atmospheric momentum to sustain the equatorial upwelling found in the SST difference map. In the tropical Atlantic
The upper level velocity potential pattern (Fig. 6a) identifying the divergent circulation illustrates two centres of action over Africa $\left(10^{\circ} \mathrm{N}, 30^{\circ} \mathrm{E}\right)$ and South America $\left(10^{\circ} \mathrm{S}, 60^{\circ} \mathrm{W}\right)$. During high-flow years the upper divergent cell is located over Africa, below which corresponding ascending motion and convection occur. In contrast, upper convergence, descending motion and drought are indicated for South America from Peru to Paraguay. The result suggests that extreme hydrological years are characterised by opposing climate anomalies over the two continents. This is supported by outgoing long-wave radiation (OLR) differences (Fig. 6b) illustrating increased convection over much of Africa concentrated in two axes along $10^{\circ} \mathrm{N}$ and $30^{\circ} \mathrm{E}$. A NW-SE band of reduced convection is found over southwestern Brazil. OLR differences along the north coast of South America are of the same sign as over Africa. 
Elsewhere across the globe (eg. the western Pacific warm pool), oceanic heat and atmospheric circulation differences in extreme hydrological years are insignificant. Hence it is suggested that an east Pacific La Nina coupled with a warm tropical Atlantic gives rise to a nearzonal overturning circulation which alternatively benefits sub-Saharan Africa at the expense of subAmazonian South America.

\section{Intra-composite anomalies for key areas}

The consistency of environmental anomalies is assessed for $10^{\circ} \times 10^{\circ}$ key areas: SSTs in the E. Pacific (equator, $95^{\circ} \mathrm{W}$ ) and $\mathrm{N}$. Atlantic $\left(25^{\circ} \mathrm{N}, 25^{\circ} \mathrm{W}\right)$, zonal wind at 700 and $250 \mathrm{hPa}$ over the tropical Atlantic $\left(2^{\circ} \mathrm{N}, 20^{\circ} \mathrm{W}\right)$, and the upper velocity potential over Africa $\left(10^{\circ} \mathrm{N}, 30^{\circ} \mathrm{E}\right)$ and S. America $\left(10^{\circ} \mathrm{S}, 60^{\circ} \mathrm{W}\right)$. From Table 2 it is noted that east Pacific SST in the three warm years of 1972 , 1982, 1983 most influence the overall pattern, whilst the north Atlantic differences are weak. For Atlantic winds, the first two years 1961 and 1962, and the 1983 El Nino make a large contribution. The upper velocity potential dipole is largely contributed by values in the $1960 \mathrm{~s}$ when observations were sparse. Opposing anomalies for SST in the East Pacific and North Atlantic key areas are consistent and correspond with a tilted zonal wind pattern linking the Pacific ENSO and the Atlantic dipole. Other influential or inconsistent cases include: upper zonal winds in 1977 and 1978, and velocity potential over South America in 1971 and 1972. Although some biases exist, the intra-composite differences are adequate to justify interpretation of climatic structure for extreme hydrological years over continents bordering the tropical Atlantic.

\section{Summary discussion}

Regional ocean-atmosphere coupling has been related to the coherent behaviour of African river flows. Interannual variability of the Nile, Congo, Niger and Zambezi River, and Lake Malawi were found to be significantly cross-correlated $(p<.05)$ over the period 1950 to

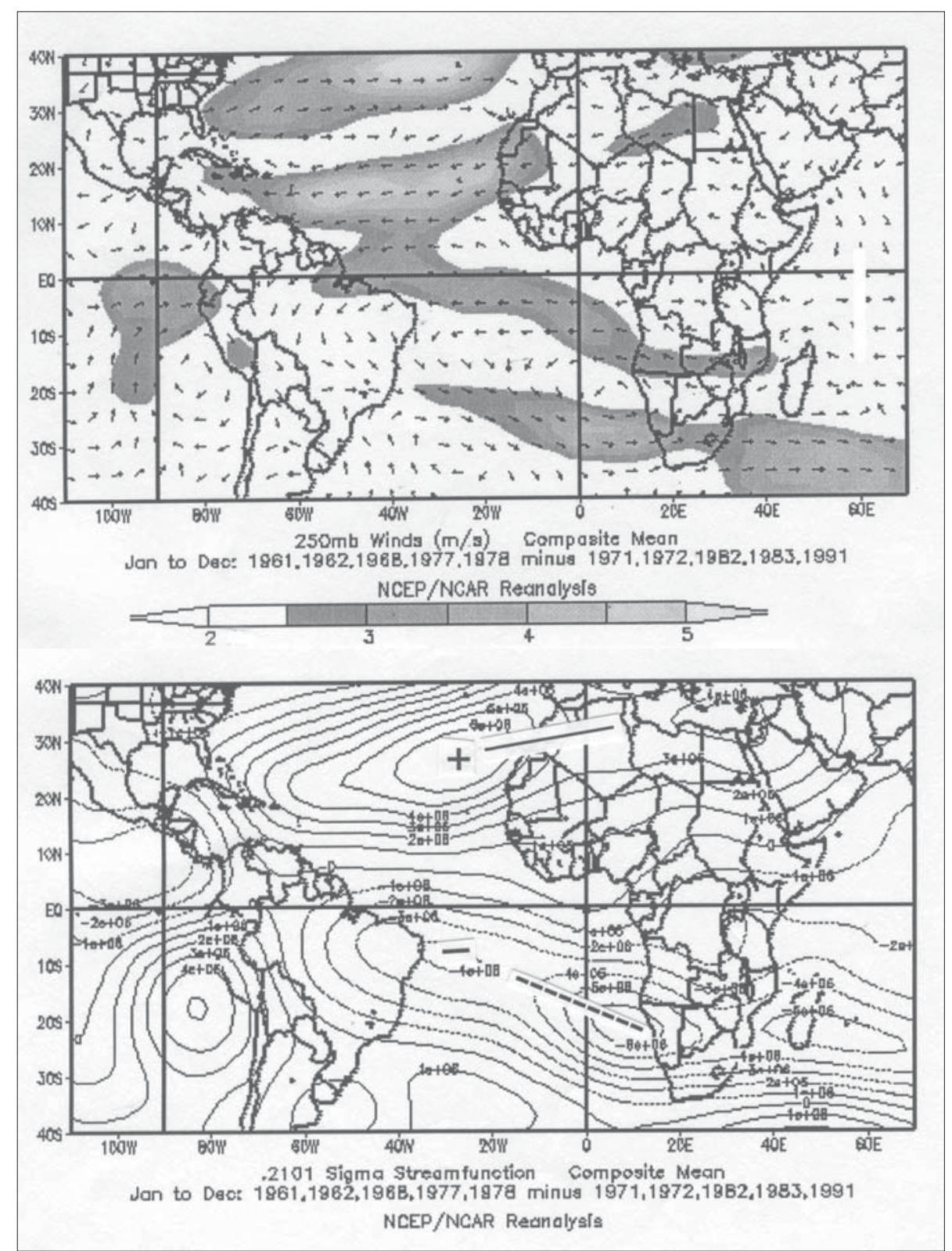

Figure 5

$250 \mathrm{hPa}$ level vector wind differences for the composite year

(a), where shaded areas are significant. Upper $(\sim 200 \mathrm{hPa})$ streamfunction composite differences (b), describing the rotational flow contribution.

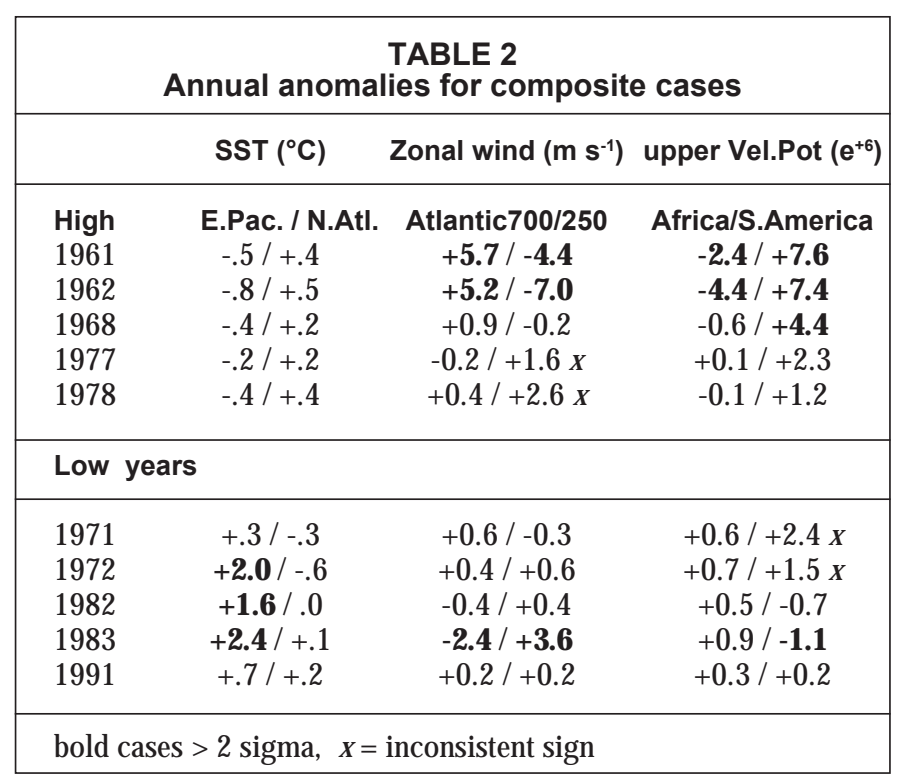




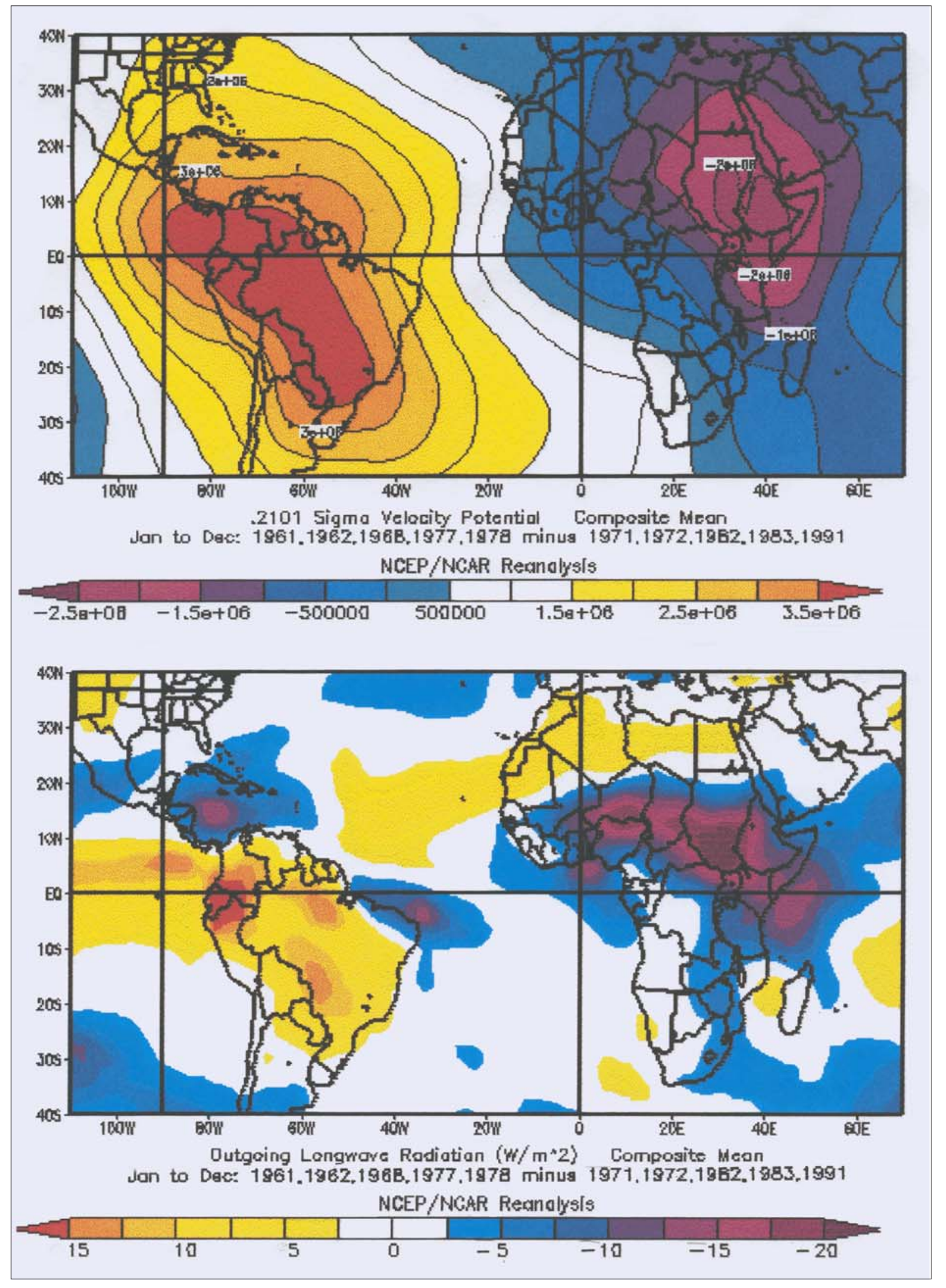

Figure 6

Upper ( 200 hPa) velocity potential differences (a) and OLR (b) for the composite year, showing centres of opposing action over Africa and South America. Blue shades = enhanced upper outflow and convection,

yellow lorange = subsident dry weather. 


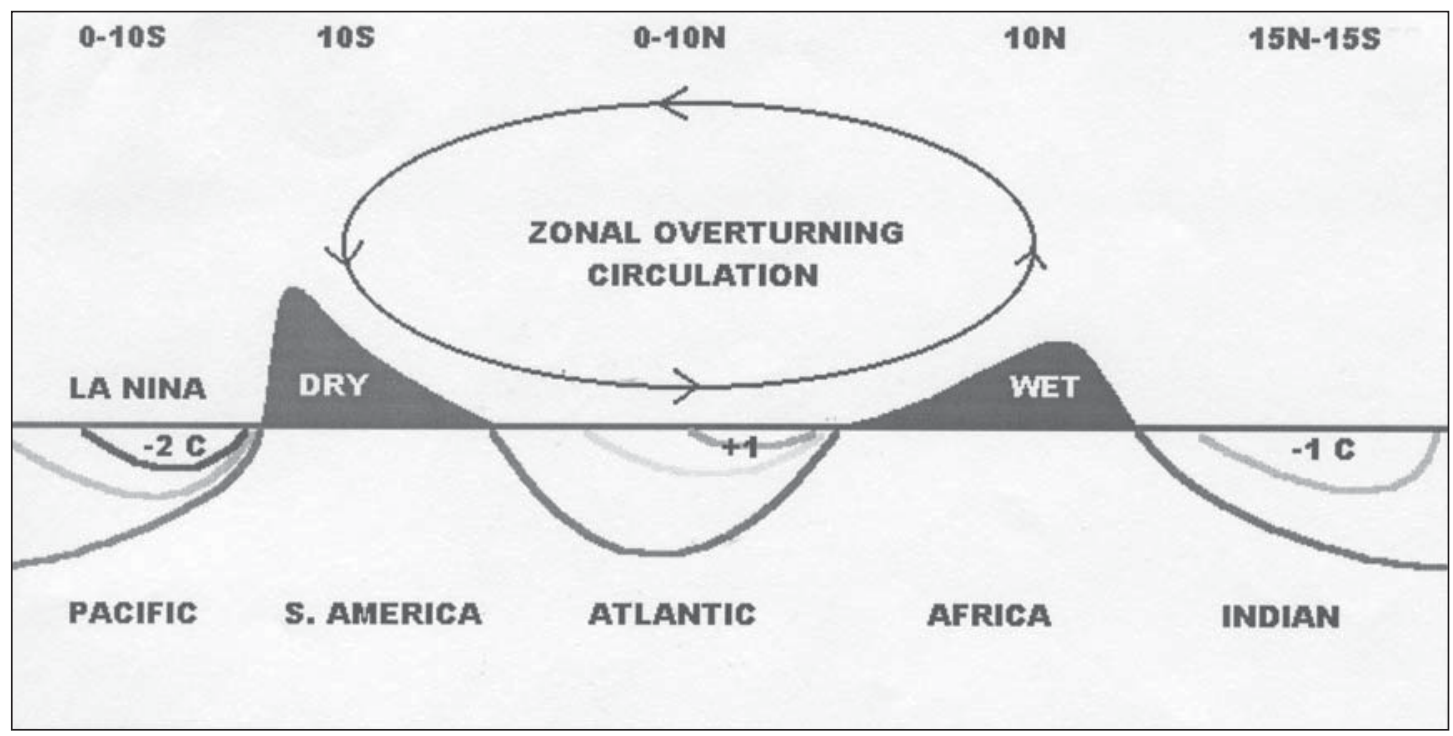

Figure 7

Schematic diagram showing the oceanic anomalies and circulation patterns relevant to years with high river flow across Africa

1995, following removal of the mean trend. A combined African river- flow index was formulated to analyse climatic factors governing extreme years and composites of NCEP reanalysis fields for high $(1961,1962,1968,1977,1978)$ and low $(1971,1972$, 1982,1983, 1991) flow years were compared. SST differences with respect to high-flow years indicated:

- $\quad$ sustained La Nina conditions in the east Pacific

- an inter-hemispheric dipole in the Atlantic (warm - north)

- below normal SST in the west Indian Ocean,

- warming of the equatorial east Atlantic (consistent with its opposing response to Indo-Pacific ENSO), and

- an inactive west Pacific warm pool.

Regarding the atmospheric circulation, upper wind differences were easterly and symmetrical about the equator. Such a pattern may explain why the inter-annual variability of water resources south of the equator is correlated with those of the north at leads and lags of six months. Westerly wind differences were found over the tropical Atlantic from the surface to $600 \mathrm{hPa}$, particularly along the Guinea coast during high-flow years. A zonal overturning circulation is revealed in the NCEP reanalysis data.

Composite difference fields for OLR and upper velocity potential demonstrated two distinct centres of action on either side of the tropical Atlantic. Convection over Africa (along two axes: $10^{\circ} \mathrm{N}, 30^{\circ} \mathrm{E}$ ) was found to be offset by sinking motions over South America (NW-slanted axis: $10^{\circ} \mathrm{S}, 60^{\circ} \mathrm{W}$ ). It is not clear how much of the signal may be attributable to observational trends, or to a real decadal rhythm in the divergent atmospheric flow.

To test the assumption of "convective polarity" between the two continents, annual river flow data for South America were obtained (Amerasekara et al., 1997). Tropical Amazon River flows are uncorrelated with the African river index shown in Fig. $2 b(r=$ $+0.01)$. The subtropical Parana River exhibits a gradual rising trend and is negatively correlated $(r=-0.31)$, more significantly so with the Niger River $(r=-0.42)$. It is concluded that convective polarity in this climate mode applies to South America west and south of the Amazon catchment, in agreement with Amerasekara et al. (1997). Further research employing longer records could evaluate ENSO influence by stratifying cases accordingly.
In this study widespread hydrological anomalies over the adjacent continents of Africa and South America were found to be sensitive to coupling between the zonal circulation over the tropical Atlantic, the global ENSO phase and the Atlantic dipole. These geophysical features interact to delay the change of ENSO phase, creating a 'two-years-at-a-time' hydrological impact. Under these conditions the wave one pattern in the global divergent circulation shifts, and centres of opposing action 'close up' over South America and Africa as shown schematically in Fig. 7. The concept is simple: climatic anomalies over the two continents are governed by ENSO-regulated coupling of the Pacific Ocean and the Atlantic Walker cell. This interaction affects the sustainability of food and water resources and the economic well-being of over one billion people. Prediction and mitigation of these hydrological events is more likely given the widened scope of scientific activities in the World Climate Research Program in the coming decade.

\section{Acknowledgement}

This study was inspired by CLIVAR meetings in West Africa convened by the author with the assistance of WCRP. Funding support from the WRC and NRF is gratefully acknowledged. Thanks are due to the hydrological services of Congo, Malawi, Mali and Zambia for provision of naturalised river flow data in the respective countries. W Alexander of the University of Pretoria provided naturalised Orange River flow data. Special thanks go to E Eltahir and G Wang of MIT for naturalised Nile River data.

\section{References}

AMERASEKARA KN, LEE RF, WILLIAMS ER and ELTAHIR EAB (1997) ENSO and the natural variability in the flow of tropical rivers, J Hydrology 200 24-39

BLISS EW (1925) The Nile flood and world weather. Mem. Roy. Meteorol. Soc. 4 (36) 53-84.

CURTIS S and HASTENRATH S (1995) Forcing of anomalous sea surface temperature evolution in the tropical Atlantic during Pacific warm events. J. Geophys. Res. 100 15835-15847.

DELÉCLUSE P, SERVAIN J, LEVY C, ARPE K and BENGSSTON L (1994) On the connection between the 1984 Atlantic warm event and the 1982-83 ENSO. Tellus 46A 448-464. 
D'ABRETON PC and LINDESAY J A (1993) Water vapour transport over southern Africa during wet and dry early and late summer months. Int. J. Climatol. 13 151-170.

DESER C and BLACKMON ML (1993) Surface climate variations over the North Atlantic during winter, 1900-1989. J Climate 6 1743-1753.

ELTAHIR EAB (1996) El Nino and the natural variability in the flow of the Nile River. Water Resour. Res. 32 131-137.

ELTAHIR EAB and GONG C (1996) Dynamics of wet and dry years in West Africa. J. Climate 9 1030-1042.

ELTAHIR EAB and WANG G (1999) Nilometers, El Nino and climate variability. Geophys. Res. Letters 26 (4) 489-492.

ENFIELD DB and MAYER DA (1997) Tropical Atlantic SST variability and ENSO. J. Geophys. Res. 102 929-945.

FARQUHARSON F and SUTCLIFFE JV (1998) Regional variations of African river flows. In: Servat E, Hughes D, Fritsch J-M, Hulme M, (eds.)Water Resources Variability in Africa in the $20^{\text {th }}$ Century, Proc. Conf IAHS. 161-169.

FOLLAND CK, PALMER TN and PARKER DE (1986) Sahel rainfall and worldwide sea temperatures, 1901-85. Nature 320 602-607.

FONTAINE B, JANICOT S and MORON V (1995) Rainfall anomaly patterns and wind field signals over West Africa in August 1958-1989. J. Climate 8 1503-1510.

HASTENRATH S and LAMB PJ (1978) Heat Budget Atlas of the Tropical Atlantic and Eastern Pacific Oceans, Univ Wisconsin Press. 103 pp.

HASTENRATH S and HELLER L (1977) Dynamics of climatic hazards in Northeast Brazil. Quart. J. Roy. Meteor. Soc. 103 77-92.

HASTENRATH S (1990) Decadal-scale changes of the circulation in the tropical Atlantic sector associated with Sahel drought. Int. J. Climatol. 10 459-472.

HIRST AC and HASTENRATH S (1983) Atmosphere-ocean mechanisms of climate anomalies in the Angola - tropical Atlantic sector. J. Phys. Oceanogr. 13 1146-1157.

HOUGHTONR W and TOURRE Y (1992) Characteristics of low frequency sea surface temperature fluctuations in the tropical Atlantic. J. Climate $5765-771$.

HUANG B, CARTON JA and SHUKLA J (1995) A numerical simulation of the variability in the Tropical Atlantic Ocean 1980-88. J. Phys. Oceanogr. 25 835-854.

HURRELL JW (1995) Decadal trends in the North Atlantic Oscillation: Regional temperatures and precipitation. Sci. 269 676-679.

JANICOT S, MORON V and FONTAINE B (1996) Sahel droughts and ENSO dynamics. Geophys. Res. Letters 23 515-518.

JURY MR (1997) Southeast Atlantic warm events: Composite evolution and consequences for southern African climate. S. Afr. J. Marine Sci. 17 21-28.

JURY MR, MULENGA H and RAUTENBACH H (2000) Tropical Atlantic variability and Indo-Pacific ENSO: Statistical analysis and numerical simulation. Global Atmos. Ocean System 7 107-124.

KABANDA TA (1995) Seasonal and Intra-seasonal Dynamics and Precursors of Rainfall over Northern Tanzania. M.Sc. Thesis, Univ. of Cape Town. 219 pp.

KALNAY E et al. (1996) The NCEP/NCAR reanalysis 40-year project, Bull. Am. Meteorol. Soc. 77 437-471.

KUSHNIR Y (1994) Interdecadal variations in the North Atlantic sea surface temperature and associated atmospheric conditions. J Climate 7 141-157.

LAMB PJ (1978) Large-scale tropical Atlantic surface circulation patterns associated with Subsaharan weather anomalies. Tellus 30A 240-251.
LAMB PJ and PEPPLER RA (1987) North Atlantic Oscillation: Concept and Application. Bull. Am. Meteorol. Soc. 68 1218-1225.

LOUGH JM (1986) Tropical Atlantic sea surface temperatures and rainfall variations in Subsaharan Africa. Mon. Weather Rev. 114 561-570.

MEHTA VM and DELWORTH T (1995) Decadal variability of the tropical Atlantic Ocean surface temperature in shipboard measurements and in global ocean-atmosphere model. J Climate 8 172-190.

MOURA A and SHUKLA J (1981) On the dynamics of droughts in northeast Brazil: Observations, theory, and numerical experiments with a general circulation model. J. Atmos. Sci. 38 2653-2675.

NICHOLSON SE (1981) Rainfall and atmospheric circulation during drought periods and wetter years in West Africa. Mon. Weather Rev. 109 2191-2208.

NICHOLSON SE and ENTEKHABI D (1987) Rainfall variability in equatorial and southern Africa: Relationships with sea surface temperatures along the southwestern coast of Africa. J. Clim. Appl. Meteorol. 26 561-578.

OGALLO LJ, JANIOWIAK JE and HALPERT MS (1988) Teleconnections between seasonal rainfall over east Africa and global sea surface temperature anomalies. J. Meteor. Soc. Japan 66 (6) 807-821.

QUINN W H (1992) A study of southern oscillation-related climatic activity 622-1990 incorporating Nile river flood data. In: Diaz HF and Markgraf V (eds.) El Nino: Historical and Paleoclimate Aspects of the Southern Oscillation. 119-142.

ROPELEWSKI CF and HALPERT MS (1987) Precipitation patterns associated with El Niño/Southern Oscillation. Mon. Weather Rev. 115 1606-1626.

SARAVANAN R and CHANG P (2000) Interaction between tropical Atlantic variability and El Nino-Southern Oscillation. J. Climate 13 2177-2194.

SERVAIN J (1991) Simple climatic indices for the tropical Atlantic Ocean and some applications. J. Geophys. Res. 96 (15) 137-146.

SERVAIN J, WAINER I, DESSIER A and McCREARY JP (1998) Modes of climatic variability in the tropical Atlantic. In: Servat E, Hughes D, Fritsch J-M and Hulme M (eds.) Water Resources Variability in Africa in the $20^{\text {th }}$ Century (Proc. Conf IAHS). 45-55.

SERVATE, HUGHES D, FRITSCH J-M and HULME M (1998) Regional Variations of African River Flows, in Water Resources Variability in Africa in the $20^{\text {th }}$ century (Proc. Conf IAHS). $462 \mathrm{pp}$.

THORNCROFT CD (1995) An idealized study of African easterly waves. Part 3: More realistic basic states. Quart. J. Roy. Meteorol. Soc. 120 983-1015.

TOURRE YM and WHITE WB (1995) ENSO signals in global upperocean temperature. J. Phys. Oceanogr. 25 1317-1332.

TOURRE YM, RAJAGOPALAN B and KUSHNIR Y (1999) Dominant patterns of climate variability in the Atlantic Ocean during the last century. J. Climate 12 2285-2299.

WAGNER RG and DA SILVA A (1994) Surface conditions associated with anomalous rainfall in the Guinea coastal region. Int. J. Climatol. 14 179-199.

WARD MN (1998) Diagnosis and short-lead time prediction of summer rainfall in tropical North Africa at interannual and multidecadal timescales. J. Climate 11 3167-3191.

WOLTER K (1989) Modes of tropical circulation, Southern Oscillation, and Sahel rainfall anomalies. J. Climate 2 149-172.

ZEBIAK SE (1993) Air-sea interaction in the equatorial Atlantic region. J. Climate 8 1567-1586. 